\title{
Sustainable Forest Management a Global Review
}

\author{
Dhirender Kumar*, CL. Thakur, D. R. Bhardwaj, Nidhi Sharma, \\ Harish Sharma and Parshant Sharma
}

Depatrment of Silviculture and Agroforestry, Dr. YSP, UHF, Nauni, Solan, India

*Corresponding author

\section{A B S T R A C T}

Keywords

Sustainable Forest

Management,

Forest and

landscape

\section{Article Info}

Accepted:

15 December 2020

Available Online:

10 January 2021
Sustainable forest management is one of the recent concept to full fill the sustainable development goals. The concept relies on certain criteria and indicator. There are about nine criteria and indicator processes throughout the world. The concept was introduced in India in 1999 at Indian institute of Forest management, Bhopal. This process is known as Dry Forest in Asia Process which include nine countries of the Dry Zone Asia. India developed its National set of 8 Criteria and 37 Indicators for the Sustainable Management of its Natural Forests adopted in the National Working Plan Code 2014. Forest certification is a voluntary process whereby an independent third party (the "certifier") assesses the quality of forest management and production against a set of requirements ("standards") predetermined by a public or private certification organization. However, forest certification India was started in 2019 to set standards for certifying India's forests, their products and their sustainable management.

\section{Introduction}

The concept of sustainability began to increase in importance at the end of the 1980s and at the beginning of the 1990s with the Brundtland report (1987) and the Conference on Environment and Development held in Rio de Janeiro, Brazil, in 1992 (the so-called Earth Summit), respectively. Nevertheless, the need to preserve natural resources for use by future generations had long been recognised. However, it was not until the 18th century that the concept of sustainability was specifically referred to, as follows: "every wise forest director has to have evaluated the forest stands without losing time, to utilize them to the greatest possible extent, but still in a way that future generations will have at least as much benefit as the living generation" (Jorge and Julio, 2012). Nevertheless, nowadays more and more researchers think climate change is changing the paradigm and sustainability shouldn't be referred to what we had before.The General Assembly of the United Nations adopted in December 2007 the most widely, intergovernmental agreed definition of Sustainable Forest Management (SFM):

"Sustainable forest management as a dynamic and evolving concept aims to maintain and enhance the economic, social and 
environmental value of all types of forests, for the benefit of present and future generations."

The Sustainable Development Goals (SDGs) are a collection of 17 global goals designed to be a "blueprint to achieve a better and more sustainable future for all". The SDGs, set in 2015 by the United Nations General Assembly and intended to be achieved by the year 2030, are part of UN Resolution 70/1, the 2030 Agenda.

Between 1990 and 2015, the world's forest area decreased from 31.6 percent of the global land area to 30.6 percent, but the pace of loss has slowed down in recent years. The loss of forests occurs mainly in developing countries, particularly in sub-Saharan Africa, Latin America and Southeast Asia. As populations increase and forest land is converted for agriculture and other uses. In some parts of Asia, North America and Europe, forest area has increased since 1990 due to large-scale afforestation programmes in several countries, as well as the natural reversion of lowproductive agricultural land back to forest. The restoration of forests and landscapes is part of global efforts to reverse forest cover loss. One of the Global Forest Goals of the UN Strategic Plan for Forests aims to reverse the loss of forest cover and increase forest area by 3 percent worldwide by 2030.The New York Declaration on Forests endorsed calls to cut natural forest loss in half by 2020, and to end it by 2030. Forest and landscape restoration (FLR) contributes to the restoration of degraded forest, and more generally to combatting land degradation.

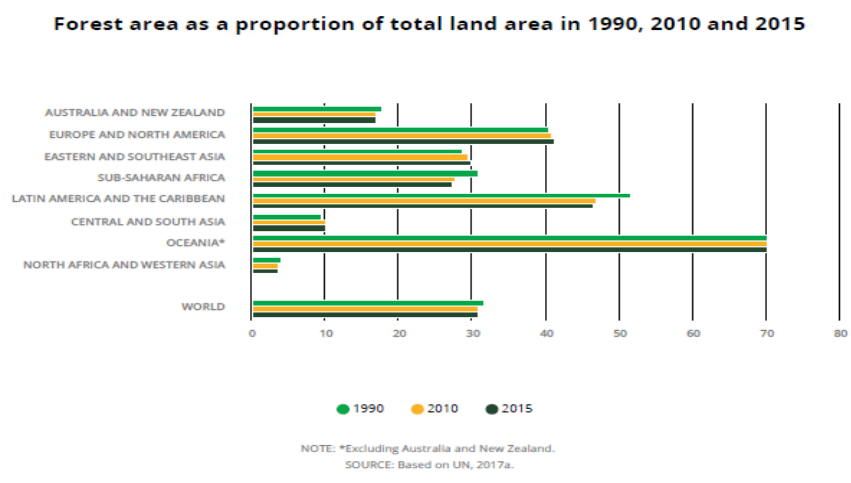

Criteria and Indicators for sustainable forest management (Source: Keenan et al 2015)

Criteria define the essential elements against which sustainability is assessed. Each criterion relates to a key element of sustainability, and may be described by one or more indicators.

Indicators are parameters which can be measured and correspond to a particular criterion.

The overall aim of criteria and indicators is to promote more sustainable forest management practices, taking into consideration the social, economic, environmental, cultural and spiritual needs of different stakeholders.

Approximately 150 countries have been participating in one or more of the nine regional criteria and indicator processes. 
1.3.2 International criteria and indicator processes

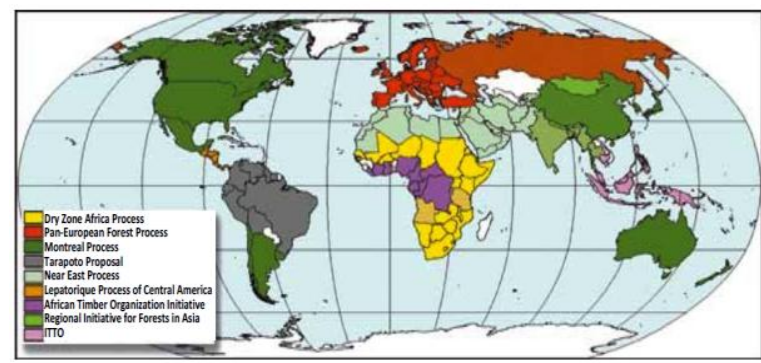

Source: FAO (2010a)

Seven common thematic areas (or criteria) of SFM acknowledged by the international forest community in the United Nations Forum on Forests (UNFF) adopted in 2007 by the UN General Assembly in the Non-Legally Binding Instrument on All Types of Forests.

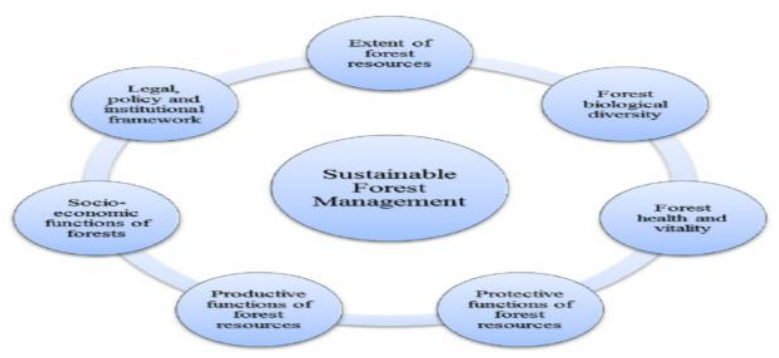

(MacDicken et al., 2015)Using the SFM related data collected through FRA 2015, it is possible to begin with the area of permanent forest land and evaluate how much forest land is covered by successive indicators. It begins from the left, showing how forest area changes with the level and presence of enabling conditions for SFM. Moving from left to right the area of permanent forest subject to each of the indicators listed on the horizontal axis is given. This reduction is based on the global extent of supportive legal, data availability, management planning and stakeholder involvement in operations. In those countries with permanent forest, some $98 \%$ of permanent forest land is covered by policies, laws and regulations in support of SFM. This indicates a broad intention on the part of governments to support SFM into the future on some 2.2 billion ha (55\% of global forest area in 2015). When all of the SFM tools are included, the area decreases to 1.11 billion ha globally.

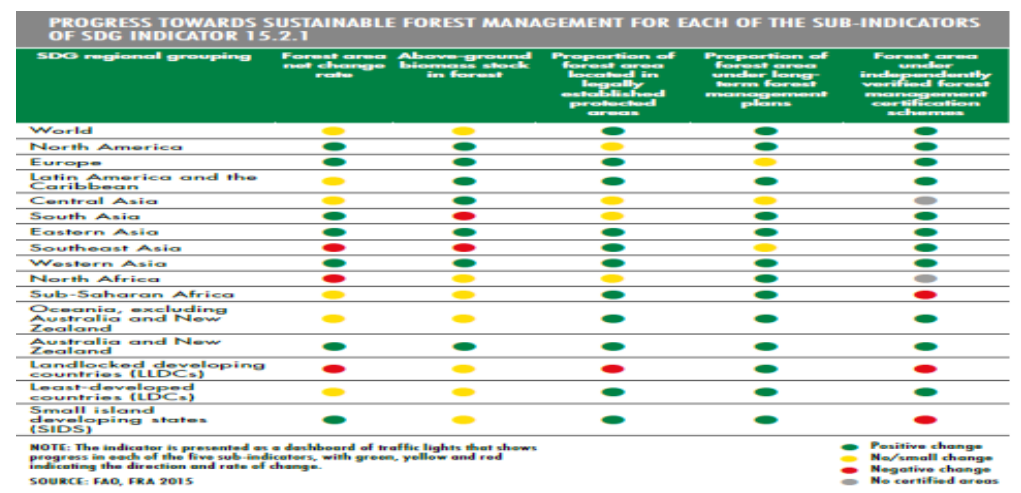




\section{Forest Certification (FAO, 2018)}

Forest certification is a voluntary process whereby an independent third party (the "certifier") assesses the quality of forest management and production against a set of requirements ("standards") predetermined by a public or private certification organization.

\section{Why might forest managers be interested in certification?}

To get better prices for their products,

To maintain or increase access to markets for their products,

To improve their public image, and to achieve social and environmental goals.

\section{What is behind the idea?}

Forest certification is a market mechanism to promote the sustainable use and management of forests and to identify "sustainably produced" products for the consumer.

The aim is to reward forest managers who pursue sustainable forest practices rather than practices with the potential to cause negative economic, social and environmental impacts.

A certification label informs potential buyers that the product was produced in a wellmanaged forest in accordance with a given set of standards.

Consumers concerned about social and environmental issues are expected to give preference to products carrying such a label, and they may also be prepared to pay higher prices for them.

Worldwide, there are two internationally recognized systems for the certification of sustainable forestry management

Forest Stewardship Council (FSC) established in the early 1990s.
Programme for the Endorsement of Forest

Certification (PEFC) formed in 1999

More than 25 years ago, the 1992 Earth Summit in Rio failed to produce an agreement to stop deforestation.

FSC was established in the early 1990s -with the support of environmental organizations such as Greenpeace, Friends of the Earth and the World Wildlife Fund (WWF) to address consumer concerns about the indiscriminate and often illegal logging of tropical hardwoods, and the knockon effects on climate change.

FSC was initially unsuited as it could not accommodate 'group certification' so every individual owner would have to be separately.

As a result, PEFC was formed in 1999 and quickly developed a group certification model that made the certification of small forest areas possible and more cost-effective.

PEFC is the largest certification framework in terms of forest area, accounting for about two-thirds of the total certified area worldwide, while the FSC is the fastest-growing scheme (by certified area).

\section{Sustainable Forest Management in India Forest management in India (Rawat et al., 2008)}

The forestry sector in India is among the first in the world to be managed on the lines of modern scientific management.

However, the basic change in perception was brought by the National Forest Policy of 1952, to focus on meeting objectives of maintaining ecological balance on the one hand and meeting the needs of stakeholders in the best possible way on the other.

The 1988 National Forest Policy focused on 
the maintenance of environmental stability, conservation of natural heritage by preserving the natural forests and meeting the basic needs of people etc,

There is however an urgent need to monitor and ensure proper implementation of these policy implications.

The quantifiable approach like criteria and indicators to monitor and implement these objectives of sustainability is imperative.

\section{The Indian initiative}

In 1999, a workshop on 'Development of National Level Criteria and Indicators for the Sustainable Management of Dry Forests in Asia' was held at the Indian Institute of Forest Management (IIFM), Bhopal.

Now referred to as the 'Dry Forest in Asia Process'.

The Bhopal-India Process is one of the nine global initiatives on Criteria and Indicators approach for Sustainable Forest Management.

Includes nine countries of the Dry Zone Asia (Bangladesh, Bhutan, China, India, Mongolia, Myanmar, Nepal, Sri Lanka, and Thailand).

Working on 8 Criteria and 48 Indicators of Bhopal-India Process, India developed its National set of 8 Criteria and 37 Indicators for the Sustainable Management of its Natural Forests adopted in the National Working Plan Code 2014,

The criteria and indicators approach has over the years endeavoured to provide a working framework for the achievement of a site-specific set of sustainability indicators of forests.

Applicability of indicators of sustainable forest management within the broad framework of the criteria varies with the specific forestry conditions.
Forest certification in India (Yadav et. al., 2007)

India now has a globally recognized forestcertification scheme developed specifically for Indian forests.

On March 4, 2019, the council of Programme for Endorsement of Forest Certification (PEFC), the international non-profit that provides independent third-party certification for sustainable forest management in India.

The Network for Certification and Conservation of Forests (NCCF) was set up in 2015 with an aim to set standards for certifying India's forests, their products and their sustainable management.

As several developed countries have put trade restrictions on import of non-certified timber, non-timber forest products and wood-based goods into their countries, getting sustainable forest management certificates has become mandatory for exports.

In fact, forest-based industries in India, particularly those for paper, boards, plywood, medium density fiberboard, furniture and handicrafts etc, have been pushing for forest certification to enhance their market accessibility to western markets including European Union and USA.

"The NCCF's forest certification scheme is aimed to improve India's forest management regime that is often criticized for various issues ailing the sector such as forest rights, forest degradation, biodiversity losses, encroachments, lack of manpower, etc.

$\begin{aligned} & \text { Sustainable forest } \\ & \text { programmes }\end{aligned}$ Management

\section{FAO}

Strengthening Institutional Capacities for Sustainable Mountain Development in the 
Indian Himalayan Region.

Strengthening Agriculture and Allied Sector Contributions to India`s National Biodiversity Action Plan (NBAP) 2008.

Green Agriculture; Transforming Indian agriculture for global environmental benefits $\&$ conservation of biodiversity and forest (2018-25) project.

\section{World bank}

India Ecosystems Service Improvement Project.

Sustainable Livelihoods and Adaptation to Climate Change Project.

Integrated Coastal Zone Management project.

National Rural Economic Transformation Project.

Meghalaya Community-led Landscapes Management Project.

Watershed Management Project being implemented in Himachal Pradesh, Uttarakhand and Karnataka.

\section{National Action Plan on Climate Change} (NAPCC)

Mission on sustainable habitat.

National mission for sustaining Himalayan ecosystems.

National mission for a "Green India".

National Mission on Strategic Knowledge on Climate Change.

Different schemes under Ministry of environment, forestry and climate change

National River Conservation Plan.

National Afforestation Programme: A Participatory Approach to Sustainable Development of Forests.

National Action Programme to Combat Desertification.

National Mission on Himalayan Studies.

\section{In Himachal Pradesh}

Smriti Van Yojana

Intensification of Forest Management Scheme Nagar Van UdyanYojana -"Ek Kadam Hariyali Ki Or" - A Programme for Climate Smart Green Cities

Himachal Pradesh Forest Ecosystems Climate Proofing Project (Germany Development Bank, assisted)

Himachal Pradesh Forest Ecosystems Management and Livelihood Improvement Project

World Bank Aided Himachal Pradesh Forests for Prosperity Project

Mid-Himalayan Watershed Development Project

Barrier to sustainable forest management

\section{Governance}

Lack of serious intent by the major staekholders (governments, industries, communities)

High opportunity cost of maintaining forests as forests

Lack of tenure security or unclear tenure and resource rights.

\section{Economy}

Excessive costs and lack of clear financial benefits from improved management vs Business as usual

Inappropriate wage systems for forest workers Inefficiency and waste in the forest and along the market chain

\section{Knowledge and technical guidance}

Inadequate information or knowledge about improved management

Improved management regulations appear too complicated for unrealistic

Lack of trained staff to implement improved management 
Fig.1

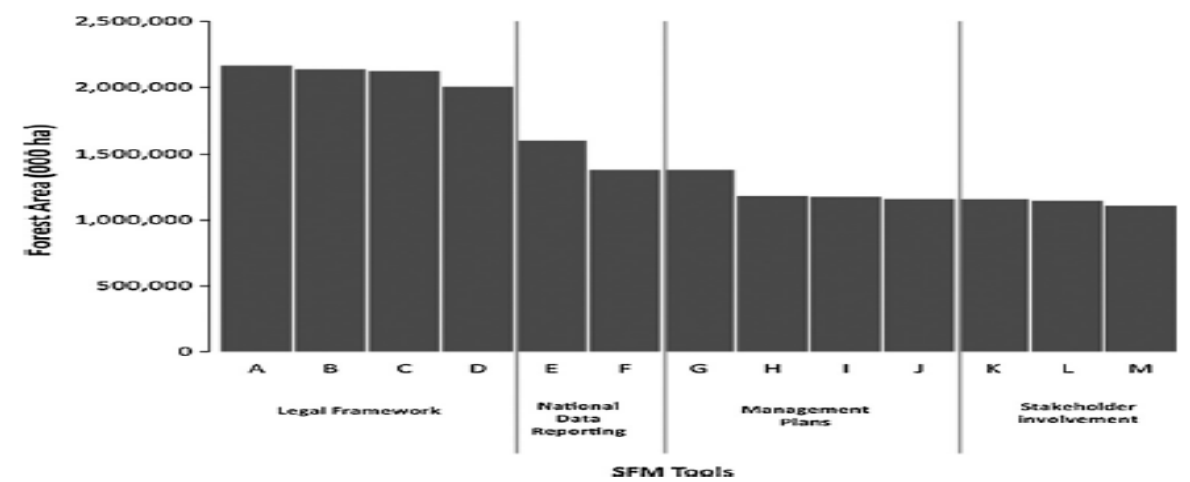

Fig. 1. The area of permanent forest use as modified by other elements of the SFM enabiing environment: (A) Permanent forest use: (B) Policies: (C) Legislation: (D) management plans; (H) Soil and water conservation; (I) High conservation value forest: (I) Social engagement; (K-M) Stakeholder involvement in operational planning. operations and review

Fig.2

\begin{tabular}{|c|c|}
\hline Criteria & Indicators \\
\hline \multirow{4}{*}{$\begin{array}{l}\text { 1. Maintenance } \\
\text { /increase in the } \\
\text { extent of forest and } \\
\text { tree cover }\end{array}$} & 1.1 Area of the forest under different forest Acts / management Plans \\
\hline & 1.2 Percentage of forest with secured boundaries. \\
\hline & 1.3 Change in area of forest cover- dense, open, scrub forests, pastures, deserts etc. \\
\hline & 1.4 Change in tree cover outside forest area \\
\hline \multirow{7}{*}{$\begin{array}{l}\text { 2. Maintenance, } \\
\text { conservation and } \\
\text { enhancement of } \\
\text { biodiversity. }\end{array}$} & 2.1 Protected area network \\
\hline & 2.2 Species diversity \\
\hline & 2.3 Genetic diversity \\
\hline & 2.4 Status of Biodiversity conservation in forests. \\
\hline & 2.5 Status of Species prone to over exploitation \\
\hline & 2.6a Status of non-destructive harvest of wood. \\
\hline & 2.6b Status of non-destructive harvest of Non-Timber Forest Produce (NTFP) \\
\hline \multirow{6}{*}{$\begin{array}{l}\text { 3. Maintenance and } \\
\text { enhancement of } \\
\text { forest health and } \\
\text { vitality }\end{array}$} & 3.1 Status of regeneration \\
\hline & 3.2a Area affected by forest fires \\
\hline & 3.2b Area damaged by natural calamities. \\
\hline & 3.3 Area protected from grazing. \\
\hline & 3.4 Area infested by invasive weeds in forests. \\
\hline & 3.5 Incidences of pests and diseases. \\
\hline \multirow{4}{*}{$\begin{array}{l}\text { 4. Conservation and } \\
\text { maintenance of soil } \\
\text { and water resources. }\end{array}$} & 4.1 Area treated under soil and water conservation measures. \\
\hline & 4.2a Duration of water flow in selected seasonal streams. \\
\hline & 4.2b Water bodies and wetlands in forest areas. \\
\hline & 4.2c Water level in the wells in the vicinity, (up to $5 \mathrm{kms}$ ) of forest area. \\
\hline
\end{tabular}

In conclusion the sustainable forest management is a dynamic and evolving concept and determining the progress toward SFM at the global scale is challenging. The world's forest area has decreased from 31.6 percent of the global land area to 30.6 percent, however the pace of loss has slowed down in recent years. Criteria and indicators have been made is to promote and access the sustainable forest management practices throughout the world. Forest certification i.e. FSC and PEFC are the two most widely used tools to achieve goal of sustainable forest management. It is clear that progress in establishing the conditions for SFM is being made: policies and legislation are generally in place over most of the global forest area, stakeholders are involved in various roles in recommending policy change and in forest operations planning. The presence of enabling 
conditions does not guarantee effective SFM practices but their presence can be viewed as a positive development and in many places the practice of SFM is confirmed by certifiers. Overall, the evidence shows a trend favorable to SFM globally that will help ensure forests remain a valued part of our common future.

\section{References}

FAO. 2010. Global forest resources assessment, 2010 - Main report. Food and Agricultural Organization of the United Nations Forestry Paper 163, Rome, Italy.

FAO. 2018. The State of the World's Forests 2018 - Forest pathways to sustainable development.Rome.

Jorge MG and Julio JD. 2012. Sustainable Forest Management: An Introduction and Overview, Sustainable Forest Management - Current Research, Dr. Julio J. Diez (Ed.), ISBN: 978-953-510621-0, InTech, Available from: http://www.intechopen.com/books/susta inable-forest-managementcurrentresearch/sustainable-forest- management-an-introduction-andoverview

Keenan R, Reams G, Freitas J, Lindquist E, Achard F, Grainger A. 2015.Dynamics of global forest area: results from the 2015 Global Forest ResourcesAssessment. Forest Ecology and Management.352. 9-20.

MacDicken KG, Sola P, Hall JE, Sabogal C, Tadoum M and Wasseige C. 2015. Global progress toward sustainable forest management. Forest Ecology and Management. 352:47-56.

Rawat TS, Menaria BL, Dugaya D and Kotwal, PC. 2008. Sustainable forest management in India. Current science. 996-1002.

Yadav M, Kotwal PC and Menaria BL. 2007. Forest certification: a tool for sustainable forest management. Bhopal, India, Indian Institute of Forest Management (also available at: www.iifm.ac.in/sfmfc/ Monograph\%20on\%20Forest $\% 20$ Certification.pdf).

\section{How to cite this article:}

Dhirender Kumar, CL. Thakur, D. R. Bhardwaj, Nidhi Sharma, Harish Sharma and Parshant Sharma. 2021. Sustainable Forest Management a Global Review. Int.J.Curr.Microbiol.App.Sci. 10(01): 2521-2528. doi: https://doi.org/10.20546/ijcmas.2021.1001.292 